\title{
Current Status of Bacterial Wilt (Ralstonia solanacearum) Disease in Major Seed Potato (Solanum tuberosum L.) Growing Areas of Ethiopia
}

\author{
Lemma Tessema $^{1 *}$, Ebrahim Seid ${ }^{1}$, Gebremedhin Woldegiorgis ${ }^{1}$, Kalpana Sharma ${ }^{2}$ \\ ${ }^{1}$ Ethiopian Institute of Agricultural Research, Holetta Agricultural Research Centre, P.O. Box 2003, Addis Ababa, Ethiopia; ${ }^{2}$ Interna- \\ tional Potato Center, ILRI Campus, P. O. Box 25171-00603 Nairobi, Kenya
}

\begin{abstract}
On-site assessment and detection of plant diseases is a prerequisite to inspect the health status of seed potatoes and to make cost-effective disease management decisions. The present study was conducted in 60 major seed potato producing cooperatives of Ethiopia to assess the extent of potato bacterial wilt disease and to generate information on current status of $R$. solanacearum. The field assessment and inspection survey was conducted during 2015/16 for 3 seasons in 140 potato fields covering 123.30 hectares of seed potato. Symptomatic plants were confirmed for $R$. solanacearum by Agri Strip kit, potassium hydroxide $(\mathrm{KOH})$ test and vascular flow (VF) techniques. The results of the study indicated that out of 140 seed potato fields assessed, 26 (equivalent to $18.57 \%$ ) or some $33.3 \%$ of seed cooperatives were infested by bacterial wilt. The highest disease incidence $(82.5 \%)$ was recorded in Jeldu district followed by Wonchi district $(60 \%)$ where most of seed potato is being distributed to the country. Based on the results of three disease confirmation tools (Agri Strip, KOH and VF) implemented, 34.75 (28.18\%) hectares of the fields showed positive results. Disease prevalence ranged from 0 to 100\%. In some districts like Cheha, Doyo-gena and Shashamane, the disease prevalence was 100\%, whereas 50\% disease prevalence was recorded in Arsi-Negelle and Kofole districts. This study describes the current infestation level of bacterial wilt in major seed producing cooperatives of Ethiopia and potato production is highly threatened by Ralstonia solanacearum in most of the areas addressed by this survey.
\end{abstract}

Keywords: Agristrip; Bacterial wilt; Disease incidence; Seed cooperatives; Seed potato

\section{INTRODUCTION}

Potato (Solanum tuberosum L.) is an important food security crop with great potential for poverty alleviation and one of the major root and tuber crops in the highlands and central highlands of Ethiopia. The crop has a considerable role in Ethiopia and used as a source of food and cash for approximately 4 million farming households [1]. However, potato bacterial wilt (Ralstonia solanacearum) is becoming the threatening constraint of potato production in Ethiopia [2-4]. The disease caused by Ralstonia solanacearum has wide host range, persistent nature and genomeplasticity, which enabled Ralstonia to one of economically important plant pathogens of the world $[5,6]$. Ralstonia solanacearum has been listed as one of the top ten bacterial species based on their scientific and economic importance in plant disease [7]. Moreover, no high level of resistance to bacterial wilt exists in potato cultivars, though all cultivars are not equally susceptible to the disease and some of them can give high yields in the presence of the disease $[8,9]$. $R$. solanacearum causes serious wilt disease in plants, which has a vast influence on yield and quality of many economically important crop plants around the world [10]. The host range of this pathogen is continuously increasing due to exhaustive agricultural practices at the global level [10].

Latently infected planting materials (seed potatoes) becoming a source of bacterial wilt, ensure transmission from place to place in many developing countries, including Ethiopia, where there is no organized seed certification system [2,3,11-13]. The pathogen stagnates in diseased plant debris, propagative organs such as tubers, rhizomes, suckers, or seeds of some crops [8]. Potato production in most developing nations including Sub-Saharan Africa (SSA) is being challenged by many production constraints such as Ralstonia solanacearum [14,15].

The disease incidence of bacterial wilt in improved and local varieties of potato in Ethiopia in some disease belt areas (around Shashamene) was $3.98 \%$ to $20.93 \%$ in the 1 st cycle and 26 to $53 \%$ in the 4th cycle of potato [16]. They also reported that bacterial

Correspondence to: Lemma Tessema, Ethiopian Institute of Agricultural Research, Holetta Agricultural Research Centre, P.O. Box 2003, Addis Ababa, Ethiopia, Tel: +251913530902; E-mail: lematessema@gmail.com

Received: February 26, 2020; Accepted: May 20, 2020; Published: May 27, 2020

Citation: Tessema L, Seid E, Woldegiorgis G, Sharma K (2020) Current status of bacterial wilt (Ralstonia solanacearum) disease in major seed potato (Solanum tuberosum L.) growing areas of Ethiopia. J Plant Pathol Microbiol 11:497. doi: 10.35248/2157-7471.20.11.497

Copyright: (C) 2020 Tessema L, et al. This is an open-access article distributed under the terms of the Creative Commons Attribution License, which permits unrestricted use, distribution, and reproduction in any medium, provided the original author and source are credited. 
wilt caused yield loss of 4 to $7 \%$ in improved and local varieties of ware potato in the 1 st cycle and 21 to $32 \%$ in the fourth cycle, respectively. The yield loss was 5.34 and $20.78 \%$ on improved and local varieties; whereas in the 4th cycle the loss was raised to 28.6 and $67.34 \%$, respectively, in seed potato production. According to Ayano [17] bacterial wilt disease caused a serious yield loss of 24.3 to $50 \%$ in potato during 2015 in the Chencha area of the Southern Nations Nationalities Regional State. In Kenya, infection of potato crops with bacterial wilt affects $77 \%$ of potato farms and causing up to $100 \%$ yield loss [18]. The direct yield losses by bacterial wilt disease vary widely according to the host, crop cultivars, climate, soil type, cropping pattern, and strain of R. solanacearum $[19,20]$. For instance, yield losses varied from 33 to $90 \%$ in potato and the global damage due to this serious disease exceeded $\$ 950$ million in 2004/05 [21].

In recent years, the disease prevalence of bacterial wilt increased significantly and it was probably aggravated by the distribution of latently infected seed from region to region [2,11]. The study by Bekele B, et al. also indicated that potato bacterial wilt was rapidly distributed from highly infested regions to new, hitherto uninfected areas of the country [12].

Disease prevalence of $97 \%$ was reported in 2015 [3] in the Chencha area and 80 to $90 \%$ disease prevalence was reported in 2015/2016 [22] in most seed potato production highlands of the country, areas where bacterial wilt distribution was low in the past decades. The problem was exaggerated due to lack of well-organized seed certification and regulations governing the distribution of seed tubers to any part of the country and then, combined with weak or nil seed potato quarantine system [23]. Detection of plant disease and assessment of the extent on individual plants as well as plant populations is prerequisite where crop loss must be related to disease, for plant disease inspections, for plant breeders to assess host susceptibility, to make cost-effective disease management decisions in crop production and to better understand many basic biological host-pathogen processes [24]. Using these important criteria, the study was conducted in major seed potato producing areas of Ethiopia to assess the extent of potato bacterial wilt disease and to generate information on current status of Ralstonia in most of the seed source highlands and central highlands of the country.

\section{MATERIALS AND METHODS}

\section{Study sites and sampled districts}

A three season survey was conducted in major seed producing cooperatives of Ethiopia in 2015/16. A total of 140 potato fields in 60 seed producing cooperatives of 14 Districts were assessed in the study during the three seasons of two main cropping (Meher) and irrigation (Belg) season production (Figure 1). During potato seed inspections, all relevant data such as seed source, variety, disease symptoms, disease incidences (\%), altitude of each location and their corresponding geographical position using the geographical position system (GPS, Garmin) were collected. The field assessment survey was conducted at an altitude range of 2026 to 3154 m.a.s.l located at $071029.8 \mathrm{~N}$ and $0384444.0 \mathrm{E}$ to 074851.5 $\mathrm{N}$ and $0375755.6 \mathrm{E}$. Due emphasis was given to inspecting major seed potato producing cooperatives located in 14 districts of the country. These highland potato domains or seed belt districts have been supported by the research centers and used for generating and disseminating huge amount of seed potato to many regions of the country.

\section{Sampling techniques used}

In total, 100 potato plants from each potato field was cross checked using a 'W' sampling pattern (modified cross with 10 arms and 10 potato plants were sampled at each of sampling points (Figure 2a).

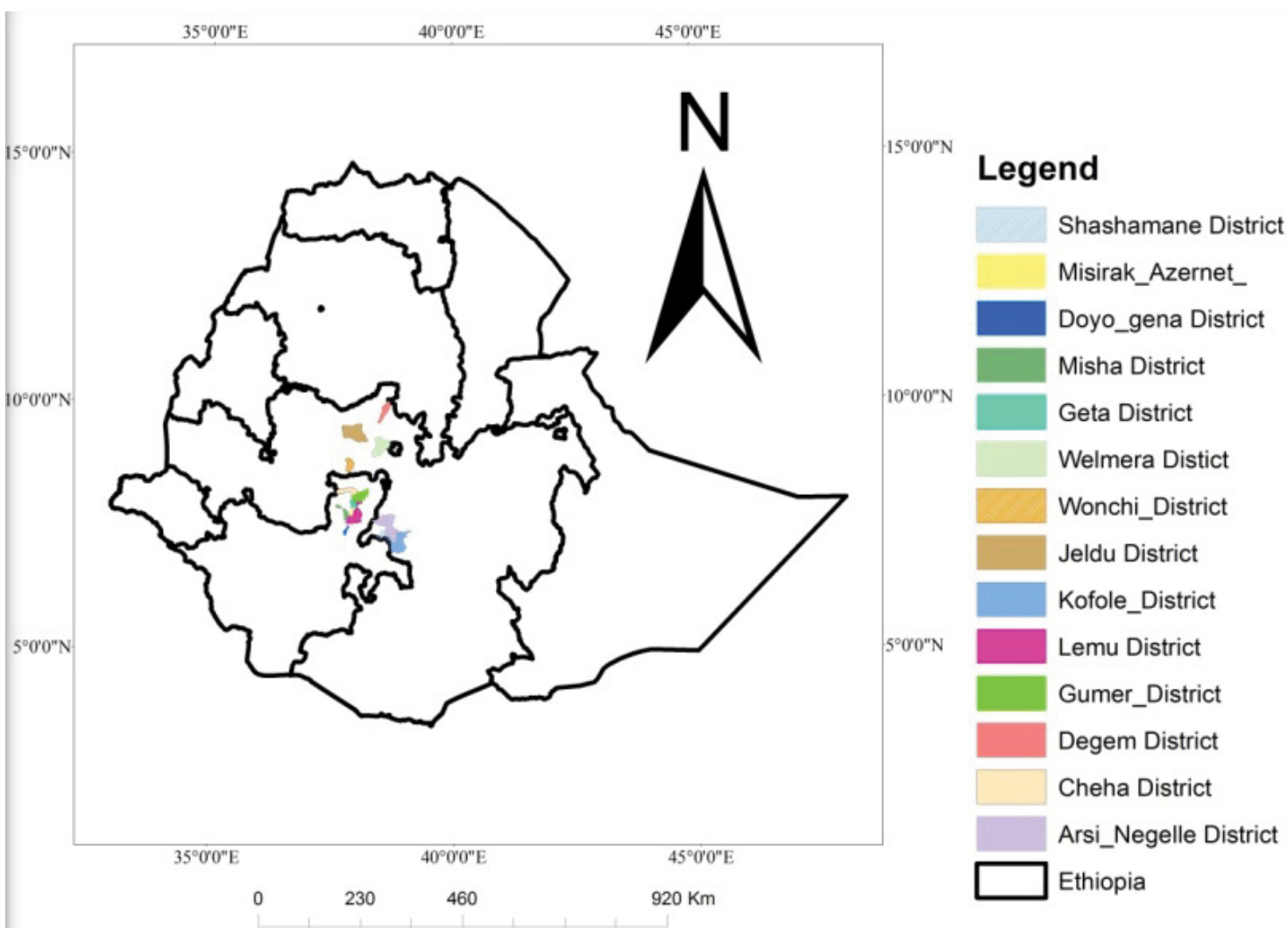

Figure 1: Map of the study districts in the field assessment at three cropping seasons. 
The length of the individual arms within a field was proportional to the size of the field. Plants within the sampling points were checked in visual observation for the presence/absence of bacterial wilt symptoms in the foliage at their flowering stage (Figure 2b).

\section{Scoring the symptomatic plants and assessment of disease severity and incidence}

After field assessment and finding plants showing the wilting symptoms from that sampling point (10 plants per sampling point) were selected randomly and rated for bacterial wilt severity. Severity was evaluated based on a $0-4$ disease scale [25]; Where: $(0=$ no symptoms of wilting, $1=0$ to $25 \%$ of plants showing wilting, $2=26$ to $50 \%$ of plants showing wilting, $3=51$ to $75 \%$ of plants showing wilting, $4=76$ to $100 \%$ of plants showing wilting.

Furthermore, data on wilt incidence were recorded in a maximum of 3-5 fields for each District. Then the percent wilt incidence was calculated by the formula:

$\%$ Wiltincidence $=$ Number fpotatofields with bacterial wilts $\times 100$ Total number of fields assessed

Disease prevalence was determined from confirmed samples and expressed as a percentage of the number of positive fields over the total number of fields assessed as adopted from Mwaniki et al. [26].
Disease prevalence $\%=$ Number of wilted plant in each field $\times 100$

Total number of plants in each field

Disease detection methods implemented during the assessment

If symptoms were observed during the field inspection, for instance Figure 3, the next step was to confirm the presence or absence of Rs from stem samples. Plant stems displaying wilt symptoms were taken from each point for the confirmation of the pathogen, employing three confirmation techniques (Poket Diagnostic KIT, $\mathrm{KOH}$ and Vascular flow) to check for the presence or absence of the pathogen. Strict sanitation measures were implemented during sample collection, detection and confirmation with the tools, to eliminate the possibility of cross-contamination. Ethanol $70 \%$ was used for disinfecting all tools, hands and other equipment.

Agri strip: is intended to confirm the presence of a specific pathogen on-site in suspicious plant samples within minutes. The reagents used for this Agri Strip were made against Rs isolate RAC 3854 from potato (originally NCPPB 3854 from the UK). This test specifically reacts with Rs with detection limits approximately $10^{5} \mathrm{cfu} / \mathrm{ml}[27]$.

Procedure: Potato stem, with petiole end approximate to $0.1 \mathrm{~g}$

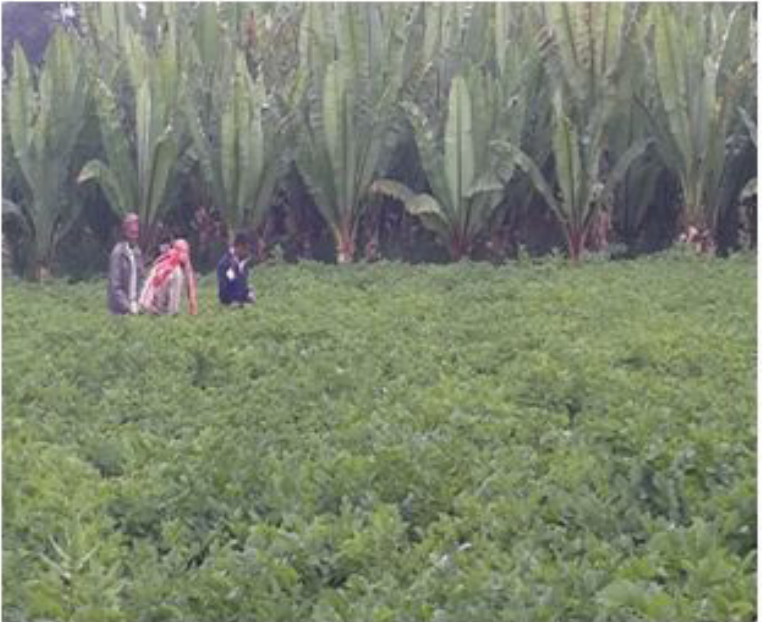

(a)

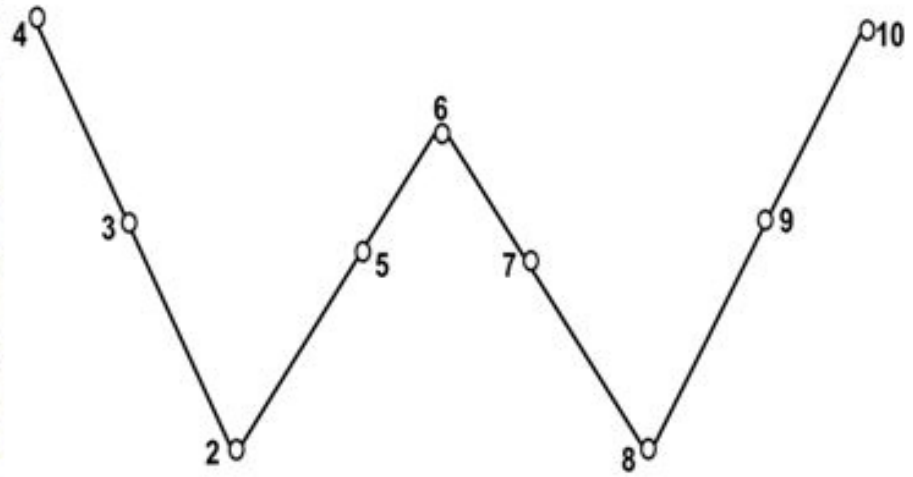

1 Main Entrance

(b)

Figure 2: (a) Field observation in Gumer district and (b) sampling techniques.
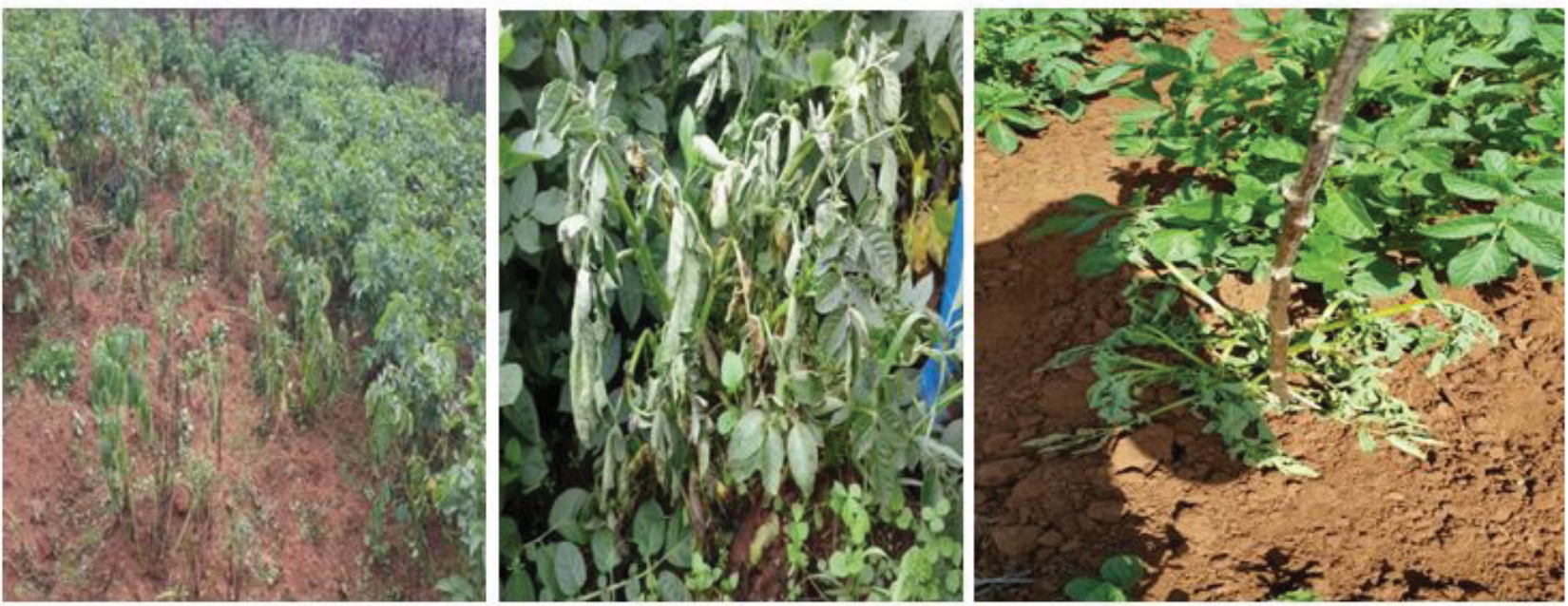

Figure 3: Bacterial wilt symptomatic plants on the field from different districts. 
$(1 \mathrm{~cm})$ was placed into an extraction bag and $3 \mathrm{ml}$ of Agri strip extraction buffer $\mathrm{B}$ was added to the bag using a disposable pipette $(1: 30 \mathrm{w} / \mathrm{v})$. The tissue was homogenized manually by hand with a few movements for about 3-4 seconds. Stems and petioles were crushed with a small conical flask glass (Figure 4a) to facilitate the release of bacterial cells into the buffer. Then 1 drop of extract was dropped into a cuvette and diluted with 3 drops of extraction buffer. The end of the strip marked «sample» was inserted into the cuvettes. Based on the observation of color forming bands, the result of the sample was confirmed as positive or negative (Figure 4b).

Potassium hydroxide $(\mathrm{KOH})$ test: was the second confirmation procedureused to support the other two techniques (Figure 4b). A sample of 5 to 10 plants/field was taken and tested by cutting the wilted stem. Two drops of $3 \% \mathrm{KOH}$ solution $(3 \mathrm{~g} / 100 \mathrm{ml}$ of distilled water) was placed on the cut surface and drawn apart slowly. Based on the study by Ahmad et al. \& Suslow et al. [28,29] the presence or absence of Ralstonia was checked by observing a fine threat of bacterial slime string and noting the viscosity, after stretching the stem to a short distance before breaking.

Vascular flow detection procedure: This technique is the oldest disease detection method and was implemented to support the above two disease confirmation methods. Five plants per sampling point were tested by cutting $5-10 \mathrm{~cm}$ stem of potato and immersed in a clear glass beaker (Figure 4c). The vascular tissue turns brown; then suspend the infected plant part in water and observe the ooze that comes out of the xylem as whitish bacterial exudates.

\section{RESULTS}

\section{Disease incidence and prevalence in seed potato fields}

The results of the present study, including the status of the disease severity in seed producing cooperatives with their respective districts are presented in Tables 1 and 2, and Figures based on descriptive data analysis. Out of 140 seed potato fields assessed, 26 (18.57\%) showed bacterial wilt infection (Tables 1 and 2). The results of the survey study in seed potato fields also indicated that wilt severity varied from 0 to 3.27 on a $0-4$ scale disease severity score. The highest disease incidence $(82.5 \%)$ was recorded in Jeldu district followed by Wonchi district (60\%), from where most of seed potato is being distributed to the country (Table 1). The highest mean bacterial wilt incidence was observed in season one (30.67\%) followed by season three $(19.38 \%)$, whereas the minimum disease incidence was observed in season two (16.14\%).

Based on the results obtained from these three disease confirmation tools (Agri Strip, $\mathrm{KOH}$ and VF), 34.75 hectares of the study fields showed positive results whereas, 88.55 hectares of the study fields showed negative results from a total of 123.30 hectares of potato fields (Table 2; Figure 4c and 5). This indicates that almost $28.18 \%$ of the area was confirmed as bacterial wilt infected and these fields could infect the next season crop if Solanaceae family crops are to be planted on those fields. The overall mean severity score for bacterial wilt disease symptoms, based on the scale $0-4$, was 1.18 ; however the severity score ranged from 0 to 3.27 in individual districts (Table 1).

The disease prevalence of bacterial wilt in the study districts was also calculated after confirmation of the presence or absence of the disease. Disease prevalence was ranked from 0 to $100 \%$. In some districts like Cheha, Doyo-gena and Shashamane, the disease prevalence was $100 \%$, whereas $50 \%$ disease prevalence was recorded in Arsi-Negelle and Kofole districts. In the other districts disease prevalence fell between 6.25 to $33.33 \%$ (Figure 6). The present study also indicated that the highest bacterial wilt prevalence was observed on potato fields for crops grown in the Belg season (offseason) production it might be due to irrigation/water source, high temperature that imposes the bacterium to manifested itself, etc.

\section{Disease symptoms and confirmation techniques}

The potato fields were assessed starting from 9:30am morning to 5:00 pm when the pathogen expresses itself well, following evaporation of the dew from plant leaves. This facilitates the identification and scoring of the wilting state of the potato plants and confirmation of the presence or absence of the pathogen by the different tools mentioned above. Regarding the tools or techniques used for disease confirmation after visualization of the symptom, Agri Strip was the latest confirmation tool and more sensitive than the other two disease detection or confirmation techniques. This is because AgriStrip could be used to specifically react with Ralstonia with a detection limit approximately $10^{5} \mathrm{cfu} / \mathrm{ml}$ [27]. Potassium hydroxide $(\mathrm{KOH})$ test was performed on site to confirm the presence or absence of bacterial wilt in potato stem sample in the field. After pouring a $3 \%$ solution of $\mathrm{KOH}$ on the stem cutting, observation of a fine threat of viscous bacterial slime, produced by

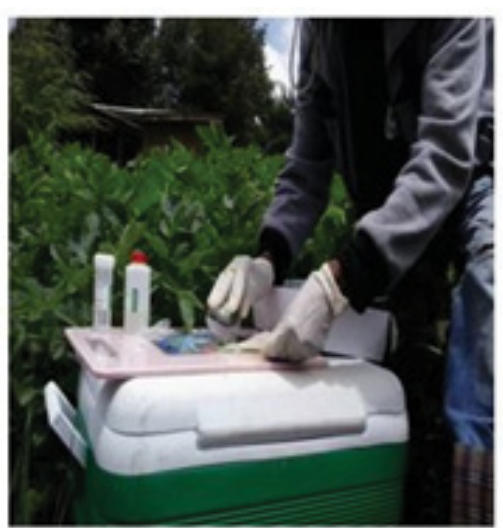

(a)

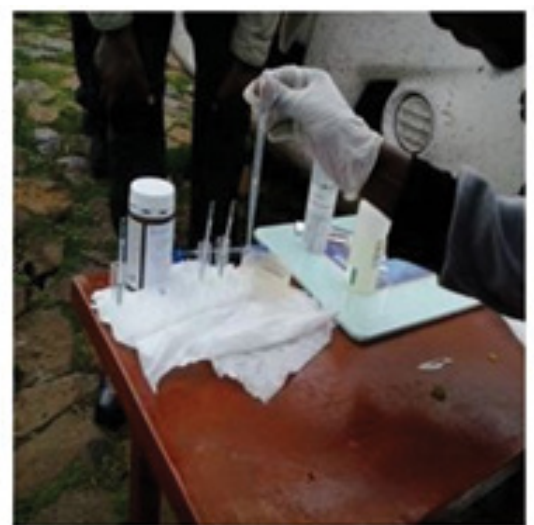

(b)

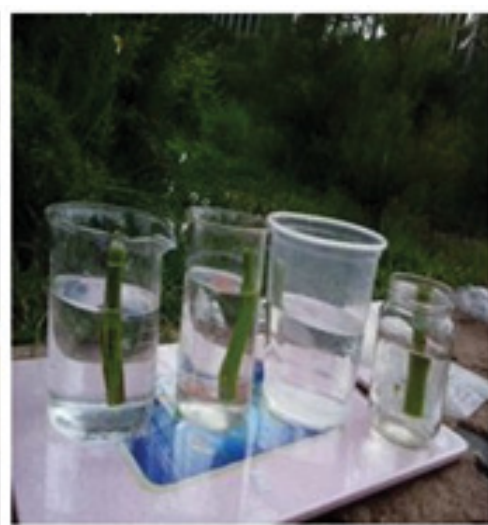

(c)

Figure 4: (a \& b) Sample crushing and preparation on field and (c) checking by vascular flow. 
Table 1: Bacterial wilt disease incidence (\%) and severity in seed potato fields during 2015/16 in major seed producing districts of Ethiopia.

\begin{tabular}{|c|c|c|c|c|c|}
\hline \multirow{2}{*}{ Districts } & \multirow{2}{*}{$\begin{array}{l}\text { Altitude m.a.s.l. } \\
\text { (in range) }\end{array}$} & \multirow{2}{*}{$\begin{array}{c}\text { Area sampled } \\
\text { (ha) }\end{array}$} & \multirow{2}{*}{$\begin{array}{l}\text { Number of fields } \\
\text { inspected }\end{array}$} & \multicolumn{2}{|c|}{$\begin{array}{l}\text { Number of fields with incidences and } \\
\text { severity }\end{array}$} \\
\hline & & & & Wilt incidence (\%) & $\begin{array}{l}\text { Wilt severity }(0-4) \\
\text { scale }\end{array}$ \\
\hline Season 1 & Aug 6-20/2015) & & & & \\
\hline Jeldu & $2777-2948$ & 65.50 & 51 & 82.5 & 3.27 \\
\hline Wonchi & $2495-2719$ & 9.25 & 16 & 60.00 & 2.12 \\
\hline Welmera & $2454-2660$ & 11 & 13 & 10.87 & 1.00 \\
\hline Gumer & $2791-2935$ & 4 & 7 & 0.00 & 0.00 \\
\hline Geta & 2791 & 0.25 & 1 & 0.00 & 0.00 \\
\hline Mean & & & & 30.67 & 1.28 \\
\hline Season 2 & (June 7-20/16) & & & & \\
\hline Cheha & $2417-2572$ & 1.25 & 2 & 23.12 & 2.01 \\
\hline Gumer & $2864-2943$ & 5.575 & 11 & 0.00 & 0.00 \\
\hline Geta & $2791-2883$ & 1.5 & 2 & 0.00 & 0.00 \\
\hline M/Azernet & $2577-3154$ & 2.5 & 6 & 0.00 & 0.00 \\
\hline Misha & $2482-2748$ & 3.5 & 4 & 0.00 & 0.00 \\
\hline Lemu & 2229 & 0.5 & 1 & 0.00 & 0.00 \\
\hline Doyo-gena & $2127-2161$ & 0.5 & 2 & 42.5 & 2.75 \\
\hline Shashamane & 2026 & 0.5 & 1 & 41.25 & 2.20 \\
\hline A/Negelle & $2504-2621$ & 1 & 2 & 29.5 & 2.05 \\
\hline Kofelle & $2662-2672$ & 1 & 2 & 25.00 & 1.98 \\
\hline Mean & & & & 16.14 & 1.10 \\
\hline
\end{tabular}

Table 2: Bacterial wilt confirmation based on AgriStrip kit, $\mathrm{KOH}$ and vascular flow tools at field level in 2015/16 in major seed potato districts of Ethiopia.

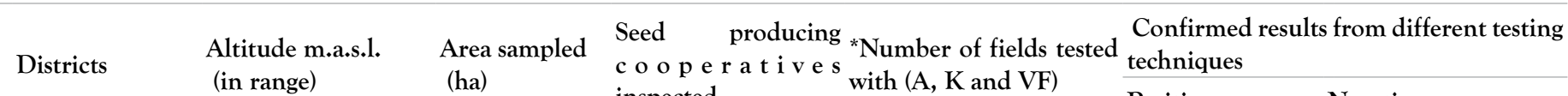
$\begin{array}{lll}\text { (in range) (ha) } & \begin{array}{l}\text { c o o p e r a t i v e s with (A, K and VF) } \\ \text { inspected }\end{array}\end{array}$

Positive Negative

\begin{tabular}{|c|c|c|c|c|c|c|}
\hline Season 1 & Aug 6-20/2015) & & & & & \\
\hline Jeldu & $2777-2948$ & 65.50 & 15 & 51 & $12(26.25)$ & $39(39.25)$ \\
\hline Wonchi & $2495-2719$ & 9.25 & 3 & 16 & $1(0.5)$ & $15(8.75)$ \\
\hline Welmera & $2454-2660$ & 11 & 2 & 13 & $2(1)$ & $11(10)$ \\
\hline Gumer & $2791-2935$ & 4 & 3 & 7 & 0 & $7(4)$ \\
\hline Geta & 2791 & 0.25 & 1 & 1 & 0 & $1(0.25)$ \\
\hline Sub-total & & 90 & 24 & 88 & $15(27.75)$ & $73(62.25)$ \\
\hline Season 2 & (June 7-20/16) & & & & & \\
\hline Cheha & $2417-2572$ & 1.25 & 2 & 2 & $2(1.25)$ & 0 \\
\hline Gumer & $2864-2943$ & 5.575 & 4 & 11 & 0 & $11(5.575)$ \\
\hline Geta & $2791-2883$ & 1.5 & 2 & 2 & 0 & $2(1.5)$ \\
\hline M/Azernet & $2577-3154$ & 2.5 & 4 & 6 & 0 & $6(2.5)$ \\
\hline Misha & $2482-2748$ & 3.5 & 3 & 4 & 0 & $4(3.5)$ \\
\hline Lemu & 2229 & 0.5 & 1 & 1 & 0 & $1(0.5)$ \\
\hline Doyo-gena & $2127-2161$ & 0.5 & 1 & 2 & $2(0.5)$ & 0 \\
\hline Shashamane & 2026 & 0.5 & 1 & 1 & $1(0.5)$ & 0 \\
\hline A/Negelle & $2504-2621$ & 1 & 2 & 2 & $1(0.5)$ & $1(0.5)$ \\
\hline Kofelle & $2662-2672$ & 1 & 2 & 2 & $1(0.5)$ & $1(0.5)$ \\
\hline Sub-total & & 17.825 & 22 & 33 & $7(3.25)$ & $26(14.575)$ \\
\hline
\end{tabular}

${ }^{*} \mathrm{~A}=$ Agri Strip, $\mathrm{K}=$ Potassium Hydroxide $(\mathrm{KOH}), \mathrm{VF}=$ Vascular Flow

${ }^{* *}$ Numbers in parenthesis are area of fields infected with bacterial wilt

stretching the stem to a short distance before breaking, was used to identify positive or negative samples. The vascular flow method is old and less reliable than the other two methods. A stem clipping of an infected plant sample was suspended in a transparent beaker of water. Within a few minutes, fine milky white threads, consisting of bacterial slime, were observed in positive samples (Figure 4c). 

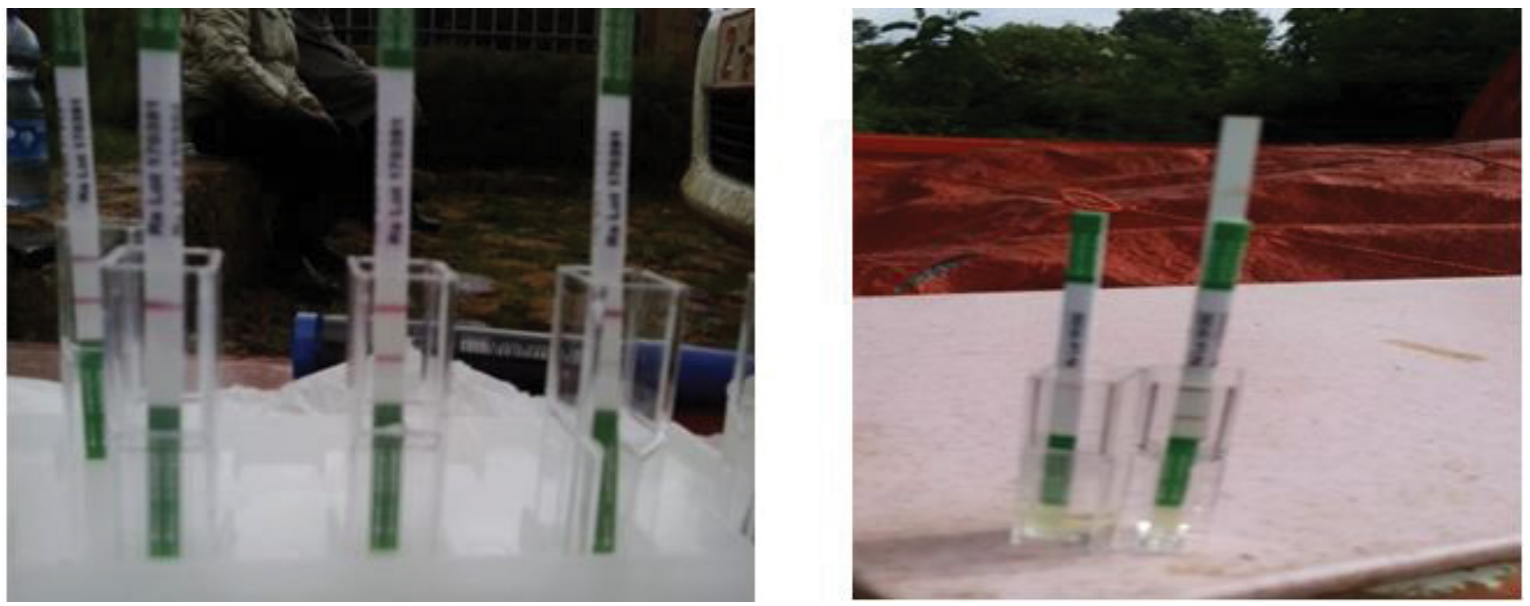

Figure 5: Negative and positive samples confirmed with Agri strip kits.

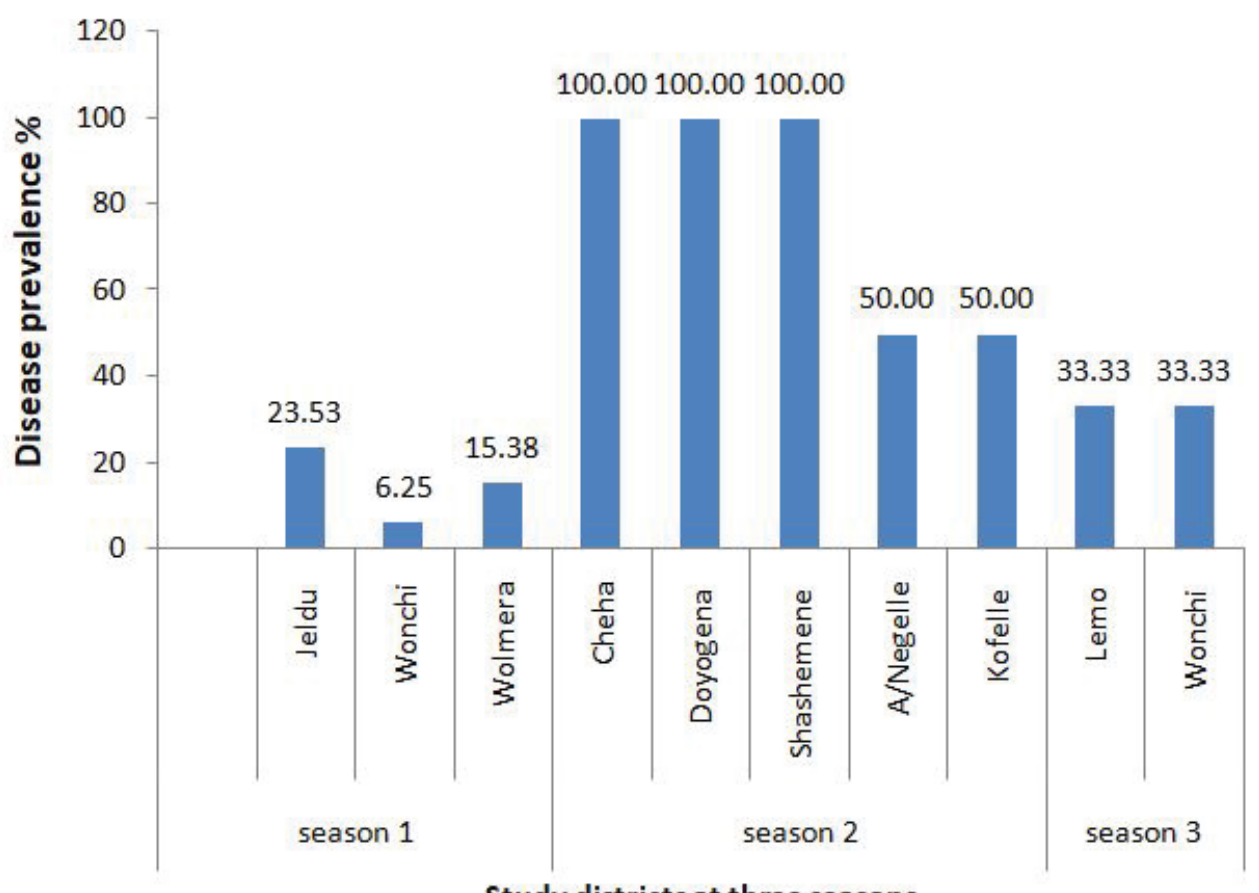

Study districts at three seasons

Figure 6: Bacterial wilt prevalence in major seed producing cooperatives/districts of Ethiopia in 2015/16.

\section{DISCUSSION}

This study describes the current infestation level of bacterial wilt in major potato seed producing cooperatives of Ethiopia (Figure 6). The purpose of the study was to inspect and identify the status of bacterial wilt progress in major seed potato source areas of the country where huge amount of seed potato is being disseminated to different parts of the country. Based on the results of study, the production of potato in Ethiopia is highly threatened by Ralstonia solanacearum. The disease is spreading suddenly from latently infected seed potato from one corner of the country to the other corner through seed exchange $[2,12]$. The disease prevalence reached up to $100 \%$ in some seed producing cooperatives/districts. In previous study by disease prevalence was $97 \%$ in Chencha district of Ethiopia in 2015 [3]. Mwaniki et al. reported bacterial wilt prevalence of 35.7 to $100 \%$ and wilt incidence of 0 to $41 \%$ in Nakuru County of Kenya [26]. On the other study by $100 \%$ disease severity and incidence was reported on potato in Rwanda [30].

The highest disease prevalence in most of seed producing cooperatives and districts could be due to lack of organized disease management actions used by seed cooperatives, potato farmers or other responsible bodies. In similar study by lack of elaborate disease management measures and poor seed system were key contributors to the extreme spread, high prevalence $(68.57 \%)$ and high incidence $(17.74 \%)$ of bacterial wilt on highland and low land solanaceous crops in Kenya [15]. In Ethiopia infected seed distribution was identified as major contributors for the spread of bacterial wilt from one parts of the country to the other part through latently infected seeds [3]. Lack of adequate extension services and weak contacts between potato farmers and extension officers was also identified as one reason of skill or knowledge limitation on bacterial wilt management and prevention methods among potato farmers in the Chencha district of Ethiopia [17]. Similarly, Mwaniki PK, et al. also reported that seed source, potato variety, lack of seed renewal etc. were major contributing factors to bacterial wilt spread in Nakuru County in Kenya [26].

On-site confirmation of symptomatic plants was undertaken from potato stems by using different Ralstonia confirmation tools. Agri Strip was one of the primary disease detection tool used for the confirmation of symptomatic samples. The Agri Stripkit used was 
a rapid diagnostic test designed to be used in the field, nursery or glasshouse. The test was simple and performed to confirm the samples within minutes to identify whether the samples were positive or negative (Figure 5). The other disease confirmation tool used on-site was the $\mathrm{KOH}$ test and it supported our detection precision by exposing the stem cutting to $\mathrm{KOH}$ and releasing viscous threads in positive samples.

Similar results were reported by Rahman MS et al, who confirmed that Gram negative bacteria had viscous threads when a glass slide was lifted and when mixed with $3 \% \mathrm{KOH}$ [31]. Ahmed et al. also reported that after exposing a plant sample to a $3 \%$ solution of $\mathrm{KOH}$, the outer membrane of Gram-negative bacteria was readily disrupted releasing the viscous DNA, confirming the presence of $R$. solanacearum in potato in Bangladesh [28].

The last confirmation method was vascular flow technique, which was performed by inserting stem cuttings of symptomatic plants to clean distilled water in clear glass beakers and observing white colored flow to the glass in positive samples. Smoke-like milky threads that streamed downward from the stem end in the glass beaker was an indicator of potato bacterial wilt in the sample [30].

The disease symptom and confirmation result indicated that there was variation in disease prevalence among the study districts and fields within a district. This might be due to the population of the bacterium in the soil, types of successive crops as pre-crop to potato, production season, cropping pattern used or knowledge within the seed producing cooperatives/farmers regarding potato bacterial wilt, access to extension services, seed source they used, the disease dynamics and strain of $R$. solanacearumin each districts $[3,17,19,20,32-34]$.

\section{CONCLUSION}

Ralstonia solanacearum diseases continue to cause significant yield losses in more than 200 plant species including potato worldwide. This result provides vital information on the current status of bacterial wilt in major seed producing cooperatives of Ethiopia. As the study was conducted on seed producing and distributing belts of the highlands and central highlands of the country, it could be used to provide preliminary information for seed producers, policy makers and other research institutions to mitigate bacterial wilt disease by commissioning further studies and appropriate disease management approaches.

\section{RECOMMENDATIONS}

This study was conducted as a preliminary field assessment and on-site confirmation of potato bacterial wilt and could be used as an indicator of the current bacterial wilt infestation level in major seed potato cooperatives/districts of the Ethiopian highlands, based on field inspection and on-site detection techniques. Further extensive molecular characterization study of the bacterial wilt pathogen that covers wider potato domain agro-ecologies of the country, including resource poor and non-cooperative individual potato farmers, could be very crucial in reducing or managing the current sudden expansion of bacterial wilt disease at nationwide level.

All seed producing cooperatives are not equally knowledgeable about potato bacterial wilt severity and its management techniques.
Hence well-organized training and an experience sharing platform must be designed and applied in a certain time interval that mobilizes the potato farmers to take action on bacterial wilt disease. Strong and organized teams in all levels, from government officials, research institution, agricultural extension officers, higher education institution, non-governmental organizations, stake holders and seed producing cooperatives as well as individual potato farmers should unite together to take action on disease management.

Strengthening disease management and legislation rules of plant quarantine system as a short time plan and thereby as a long term strategy thinking of the development and release of wilt resistant potato varieties should be implemented simultaneously. Finally, strong national seed certification system supported with strict seed testing procedure and sound quarantine rules, accompanied by a formal seed system must be implemented, with the ultimate goal of pathogen eradication from the country.

\section{CONFLICTS OF INTEREST}

The authors declared that there is no conflict of interest.

\section{ACKNOWLEDGMENTS}

The authors are thankful to the International Potato Centre (CIP), Ethiopian Institute of Agricultural Research (EIAR) and other collaborating institutions and researchers, CIP's drivers Tewodros and Fitsum, our field technicians Molla Meshesha, Tsegaye Tolcha, G/Markos Tilahun and seed cooperative farmers for their valuable cooperation and assistance.

\section{REFERENCES}

1. CSA (Central Statistics Agency). Report on Area and production of major crops (private peasant holdings, MeherSeason). Agricultural Sample Survey, Volume I. Addis Ababa, Ethiopia. 2016.

2. Sharma K, Woldegiorgis G, Tessema L, Desta T, Zegeye W, Teklu MA, et al. Tackling bacterial wilt of potato in Ethiopia. CIP Policy Brief No. 01. 2018;1-4.

3. Abdurahman A, Griffin D, Elphinstone J, Struik PC, Schulz S, Schulte-Geldermann E, et al. Molecular characterization of Ralstonia solanacearum strains from Ethiopia and tracing potential source of bacterial wilt disease outbreak in seed potatoes. Plant Pathology. 2018;66:826-834

4. Kassa B. Participatory potato (Solanum tuberosum L.) bacterial wilt (Ralstonia solanacearum (E.F. Smith.)) management in the Central Highlands of Ethiopia. Agricultural Research \& Technology. 2017;11(1):555801.

5. Elnaggar S, Mohamed AM, Bakeer A, Osman TA. Current status of bacterial wilt (Ralstoniasolanacearum) disease in major tomato (Solanum lycopersicum L.) growing areas in Egypt. Archives of Agriculture and Environmental Science. 2018;3(4):399-406.

6. Safni I, Cleenwerck I, De Vos P, Fegan M, Sly L, Kappler U. Polyphasic taxonomic revision of the Ralstonia solanacearum species complex. International Journal of Systematic and Evolutionary Microbiology. 2014;64:3087-3103.

7. Mansfield J, Genin S, Magori S, Citovsky V, Sriariyanum M, Ronald P. Top 10 plant pathogenic bacteria in molecular plant pathology. Molecular Plant Pathology. 201213:614-629.

8. Mihovilovich E, Lopes C, Gutarra L, Lindqvist-Kreuze H, Aley P, Priou $\mathrm{S}$, et al. Protocol for assessing bacterial wilt resistance in greenhouse 
and field conditions. International Cooperators' Guide. Lima (Peru). International Potato Center. 2017

9. Rupa V, Choudhary AK, Dutta A, Maurya S. Screening of some antibiotics against 'Ralstoniasolanacearum' causes Bacterial Wilt in Brinjal (Solanum Melongena L.) plants obtained from different regions of Ranchi District. International Journal of Recent Scientific Research. 2017;8(11):21405-21408

10. Choudhary DK, SUN N, Dar MS, Khan KA. Ralstonia solanacearum: A wide spread and global bacterial plant wilts pathogen. Journal of Pharmacognosy and Phytochemistry. 2018;7(2):85-90.

11. Potatoes South Africa. Factsheet: Bacterial wilt. 2015.

12. Bekele B, Abate E, Asefa A, Dickinson M. Incidence of potato viruses and bacterial wilt disease in the West Amhara sub-region of Ethiopia. Journal of Plant Pathology. 2011;93(1):149-157.

13. CIP. Harnessing Potato and Sweet potato's Power for Food Security, Nutrition and Climate Resilience. International Potato Center, Annual Report for 2017. 2018

14. Muthoni J, Shimelis H, Melis R. Management of Bacterial Wilt [Rhalstonia solanacearum] of Potatoes: Opportunity for Host Resistance in Kenya. Journal of Agricultural Science. 2012;4(9):64-78.

15. Kago KE, Kinyua MZ, Okemo OP, Muthini MJ. Bacterial wilt, a challenge in Solanaceous crops production at Kenyan Highlands and Lowlands. World Journal of Research and Review. 2016;3(1): 06-11.

16. Kassa B, Chindi A. Seed tuber cycle and latent infection for the spread of potato bacterial wilt Ralstonia solanacearum (Smith) a threat for seed production in Ethiopia. Asian Journal of Plant Pathology. 2013;7(2):74-83.

17. Ayano KT. Assessing extension approaches for bacterial wilt control with potato farmers in Ethiopia. Journal of Agricultural Economics, Extension and Rural Development. 2019;7(2):809-850.

18. Chamedjeu RR, Masanga J, Matiru V, Runo S. Isolation and characterization of Ralstoniasolanacearum strains causing bacterial wilt of potato in Nakuru County of Kenya. African Journal of Biotechnology. 2018;17(52):1455-1465.

19. Kassa B. Potato Bacterial Wilt management in the Central Highlands of Ethiopia. Ethiopian Journal of Agricultural Sciences. 2016;26(2):83-97.

20. Yadessa GB, van Bruggen AHC, Ocho FL. Effects of different soil amendments on bacterial wilt caused by Ralstonia solanacearum and on the yield of Tomato. Journal of Plant Pathology. 20101;92(2):439-450.

21. Elphinstone JG. The current bacterial wilt situation: a global overview, p.9-28. In: Allen C, Prior P and Hayward AC (ed.), Bacterial Wilt Disease and the Ralstonia solanacearum Species Complex. American Phytopathological Society Press, St. Paul, MN. 2015.

22. Sharma K, Schulte-Geldermann E. Bacterial wilt of potato, what should be done? CIP Policy Brief No. 01, Lima, Peru. 2018;1-4.
23. Gorfu D, Woldegiorgis G, Kassa B. Bacterial Wilt: An Emerging threat to Ethiopian potato industry. Pp. 211-222. In: Woldegiorgis G, Schulz S and Birhanu B (eds.), Proceedings of the National Workshop on Seed potato tuber production and disseminations: experiences, challenges and prospects. Ethiopian Institute of Agricultural Research and Amhara Region Agriculture Research Institute, Bahir Dar, Ethiopia. 2013.

24. Clive HB, Forrest WN JR. Detection and measurement of plant disease symptoms using visible wavelength photography and image analysis. CAB Reviews: Perspectives in Agriculture, Veterinary Science, Nutrition and Natural Resources. 2011;6(27):1-17.

25. Swanson JK, Yao J, Tans-Kersten J, Allen C. Behavior of Ralstoniasolanacearum race 3 biovar 2 during latent and active infection of geranium. Phytopathology. 2015;95(2):136-143.

26. Mwaniki PK, Birech R, Wagara IN, Kinyua ZM, Schult-Geldermann E, Bernhard F. Distribution, Prevalence and Incidence of Potato Bacterial Wilt in Nakuru County, Kenya. International Journal of Innovation Research and Development. 2016;5(1):435-442.

27. BIOREBA. Airstrip for Ralstonia solanacearum (Rs) detection, instructions for use. 2013.

28. Ahmed NN, Rashidul I, Muhammed AH, Bahadur MM, Mahboob HM. Determination of Races and Biovars of Ralstonia solanacearum Causing Bacterial Wilt Disease of Potato. Journal of Agricultural Science. 2013;5(6): 86-93.

29. Suslow TV, Scheroth MN, Isaka M. Application of Rapid Methods for Gram Differentiation of Plant pathogenic and Saprophytic Bacteria without Staining. Phytopathology. 1982;72:917-918.

30. Mutimawurugo MC, Wagara IN, Muhinyuza JB, Ogweno JO. Virulence and characterization of isolates of potato bacterial wilt caused by Ralstonia solanacearum (Smith) in Rwanda. African Journal of Agricultural Research. 2019;14(6):311-320.

31. Rahman MS, Her SM, Kim J, Kang S, Lee K, Uddin MJ, et al. Brucellosis among ruminants in some districts of Bangladesh using four conventional serological assays. African Journal of Microbiology Research. 2012;6(22):4775-4781.

32. Mwaniki PK, Wgara IN, Birech R, Kinyua ZM, Schult-Geldermann E, Freyer B. Impacts of crop rotation sequences on potato in fields inoculated with bacterial wilt caused by Ralstonia solanacearum. African Journal of Agricultural Research. 2017;12(14):1226-1235.

33. Kurabachew H, Ayana G. Bacterial wilt caused by Ralstonia solanacearum in Ethiopia: Status and management approaches: A review. International Journal of Phytopathology. 2016;05(03):107-119.

34. Karim Z, Hossain MS. Management of bacterial wilt (Ralstoniasolanacearum) of potato: Focus on natural bioactive compounds. Journal of Biodiversity Conservation and Bio Resource Management. 2018;4(1):73-92. 